\title{
PRIMARY SCHOOL STUDENTS' SELF-REGULATED LEARNING SKILLS IN MUSIC LESSONS
}

\author{
Ligita Stramkale \\ University of Latvia, Latvia \\ Laila Timermane \\ Dobele secondary school No 1, Latvia
}

\begin{abstract}
The topicality of the study was determined by the increasing role of self-regulated learning (hereinafter SRL) in primary education. The aim of the study is to compare the teacher's assessment with the students' self-assessment, to identify whether there are differences in awareness of the required level of SRL skills in music learning. Previous researches on SRL have been analysed, and an empirical study involving $86(\mathrm{~N}=86) 4$ th- grade students of primary school has been conducted to achieve the aim of the study. To determine the level of primary school students' SRL skills in music learning, the SRL skills of each student during music lessons were observed by the music teacher and were recorded in the observation protocol according to four criteria: motivation, setting learning outcomes, monitoring of learning and outcomes assessment. The questionnaire provided an opportunity to reveal the self-assessment of each student's SRL skills and compare them with the results obtained by pedagogical observation. The study found that there is no difference between the teacher's assessment and students' self-assessment. Both teacher and students believe that the students' skill of setting learning outcomes in a music lesson is at a low level, while the skills of monitoring their learning and assessing the outcomes are at a medium level. The study concluded that primary school students understand their SRL skills level, which is a prerequisite of monitoring learning and outcomes assessment strategies for joint learning.
\end{abstract}

Keywords: self-regulated learning skills, music lesson, a primary school student, school education.

\section{Introduction}

SRL is one of the skills that is very important in today's fast-changing society, as it helps to generate new ideas, theories, products and knowledge (Council of European Union, 2018), it is one of the cross-cutting skills included in the modern curriculum (Regulations of the National Standard..., 2018). The future requires teachers to adapt their practices to 
new challenges by ensuring the implementation of SRL, which is not only appropriate and relevant approach for primary education but also is very important for success in the future professional life and labour market.

Previous studies highlighted several features that characterized SRL. For example, Zimmerman believes that SRL is an activity where students perform a task by taking the initiative and control the situation (Zimmerman, 2002). On the other hand, a study conducted in Australia highlights the fact that self-regulated learners become responsible for learning outcomes, approaches and strategies to achieve the desired goals (Harding, Nibali, English, Griffin, Graham, \& Alom et al., 2018). Several researchers emphasize that SRL based on the formulation of goals, identification of necessary resources, selection and implementation of appropriate strategies, and assessment of learning (Zimmerman, 2011; Walsh, 2017; Adeyemi \& Oderinde, 2019).

Many researchers believe (Zimmerman, 2002; Walsh, 2017) that SRL is an essential skill that a student must acquire at school. Zimmerman argues this in the context of lifelong learning (Zimmerman, 2002), but Walsh highlights the rapidly growing amount of knowledge in recent decades, which requires active learning from a person (Walsh, 2017). SRL develops a greater desire to learn, helps to acquire knowledge, encourages purposeful and productive action (Penetration skills, 2020), and in a music lesson, it promotes intellectual curiosity and emotional engagement (McPherson, Miksza, Evans, 2017).

Teachers have a significant role in promoting students' SRL during the music lesson. The researchers believe that teachers should prepare the appropriate environment and encourage students to learn independently (Du Toit-Brits, 2019; Jaleel \& Anuroofa, 2017; Boekaerts \& Corno, 2005). The teachers should implement specific strategies that enable reflection and awareness of learning (Thornton, 2010; Cleary, 2018), use guidance and encouragement, as well as include elements of SRL in the classroom (Harding, Nibali, English, Griffin, Graham, \& Alom et al., 2018). Moreover, it is needed to give students the freedom of choice, and performance progress should be monitored and observed (Adeyemi \& Oderinde, 2019).

Teachers' SRL skills and their understanding of what forming SRL is essential as well. The researchers found out that teachers need to understand what is SRL and how should it be implemented (Callan \& Shim, 2019). Furthermore, they believed that those teachers who have SRL skills become more effective in enabling it in the learning process (Peeters, Backer, Reina, Kindekens, Buffel \& Lombaerts, 2014; De Smul, Heirweg, Devos \& Van Keer, 2018). Therefore, according to Oates, future teachers should be provided already during their study with teaching strategies based on an active, collaborative approach (Oates, 2019). 
Teachers may face disturbing factors during the implementation of SRL in the classroom. Vandeveldea and colleagues revealed that teachers do not have the opportunity to implement SRL during lessons due to the lack of time, the pressure of work and the diversity of students (Vandeveldea, Vandenbussche \& Van Keer, 2012).

To implement SRL in music lessons successfully, the teachers should determine each student's current level of SRL skills, and the students need to assess their SRL skills adequately. That helps to understand how the SRL skills can improve through collaboration and purposeful music learning process. This study aims to compare the teacher's assessment with the students' self-assessment to identify whether there are differences in awareness of the required level of SRL skills in music learning.

\section{Methodology and Materials}

The study involved $86(N=86) 4$ th-grade students in a comprehensive school (46 boys and 40 girls). The study took place during music lessons from September 2019 to December 2019. Three research questions were raised in this paper:

- What is the level of primary school students' SRL skills in music learning?

- How do primary school students evaluate their SRL skills?

- Is there a relationship between the teacher's assessment of SRL skills and the students' self-assessment?

Structured observation during the music lessons was carried out by the music teacher to answer the first research question. The SRL skills of each student were recorded in the observation protocol according to four criteria: motivation, setting learning outcomes, monitoring of learning and outcomes assessment. Three levels determined each criterion: low, medium and high. The low level refers to the arithmetic mean (M) ranging from 1.00 to 1.66 , the medium level from 1.67 to 2.32 , and the high level from 2.33 to 3.00 . The data collected by the observation process were used in an aggregated way.

A questionnaire included 12 statements describing the intended learning outcomes, monitoring of learning and outcomes assessment was created to identify the perspective of primary school students on their SRL skills. The students asked to assess each statement using a 4-point Likert scale. For data processing, the responses were coded in numbers: 4 - always, 3 - often, 2 - rarely, 1 - never. The 4-point Likert scales divided into three levels. The low level characterised by an arithmetic mean (M) ranging from 1.00 to 2.00, the medium level from 2.01 to 3.00, and the high level from 3.0 to 4.00 . The teacher's assessment and the students' self-assessment were 
compared using Pearson correlation to answer the third question raised in the study.

The Statistical Package for Social Science (SPSS) version 22 was used to analyse the collected data. The arithmetic mean (M), the standard deviation (SD) and the median (ME) were calculated. The Skewness was used to determine the normality of each variable. Skewness ranging from -0.5 to 0.5 means that the data obtained are fairly symmetrical, the range from -1 to -0.5 or from 0.5 to 1 refers to moderately skewed data, and if the data obtained are less than -1 or greater than 1 , then they are highly skewed. The Bivariate (Pearson) correlation analysis was used to determine the relationship between the criteria set out in the study.

\section{Results and Discussions}

SRL in music lesson starts with motivation. The study determined (see Table 1) that the primary school students' motivation in SRL music lesson was at a medium level $(M=1.97, S D=0.69)$. A motivated student will be able to set learning outcomes $(r=0.561, p<0.01)$ and monitor his learning $(r=0.498, p<0.01)$. Other researchers have also found that motivation affects SRL. Motivation influences students' attention, task choice, effort and persistence (Zimmerman, 2011), it is gearing towards achieving the goal and expressed in the desire to perform tasks that will lead to achieving this goal (Boyer, Edmondson, Artis \& Fleming, 2013). Motivation may be driven by internal and external encouragement. The assessment could be an external encouragement. Benders believes that internal motivation is essential in making music because it based on success (Benders, 2013).

Table 1. Primary school students' SRL level in music lessons

\begin{tabular}{lcccc}
\hline \multicolumn{1}{c}{ Criteria } & $\boldsymbol{M}$ & $\boldsymbol{S D}$ & $\boldsymbol{M E}$ & Skewness \\
\hline Motivation & 1.97 & 0.69 & 2.00 & 0.04 \\
Setting learning outcomes & 1.53 & 0.50 & 2.00 & -0.14 \\
Monitoring of learning & 2.02 & 0.70 & 2.00 & -0.03 \\
Learning outcomes assessment & 1.67 & 0.64 & 2.00 & 0.41 \\
\hline
\end{tabular}

The study found out that students in the primary school stage have a low level of skill to set the learning outcomes in a music lesson $(M=1.53, S D=0.50)$. Defining learning outcomes is closely connected with monitoring one's learning $(r=0.532, p<0.01)$. The teacher should aim at teaching students to set learning outcomes independently because, 
without that, the students will not be able to monitor their learning, which is an essential part of SRL.

Monitoring the learning process is a skill that enables students to take responsibility and learn independently. The study revealed that primary school students monitor their learning at a medium level $(M=2.02$, $S D=0.70$ ). The learning process in music lessons often takes the form of joint making music in larger or smaller groups, which requires cooperation. It means that students monitor their learning in collaboration with other classmates. To enable children at this age to drive their musical activities, the teacher needs to teach common strategies for making music. A study conducted by Dignath and colleagues considered that primary school students still do not have sufficiently developed competence to work effectively in groups (Dignath, Buettner \& Langfeldt, 2008).

Effective learning may only be possible if the students assess the outcomes achieved in music activities and determine their further action to improve it if necessary. The skill of primary school students to evaluate learning outcomes is at a medium level $(M=1.67, S D=0.64)$. The study found that the responses describing this criterion were not sufficiently symmetric ( $M=1.67, M E=2.00$ ). The uneven distribution shows that some students considered the assessment of learning outcomes as a very complicated process, while others had no trouble with that.

The students also believe that their skill to set learning outcomes at a low level $(M=1.98, S D=0.99)$, but they can monitor their learning $(M=2.92, S D=0.95)$ and assess the outcomes $(M=2.81, S D=0.89)$ at a medium level (see Table 2).

Table 2. Primary school students' perspective on SRL

\begin{tabular}{lcccc}
\hline \multicolumn{1}{c}{ Criteria } & $\boldsymbol{M}$ & $\boldsymbol{S D}$ & $\boldsymbol{M E}$ & Skewness \\
\hline Setting learning outcomes & 1.98 & 0.99 & 2.00 & 0.38 \\
Monitoring of learning & 2.92 & 0.95 & 3.00 & -1.01 \\
Outcomes assessment & 2.81 & 0.89 & 3.00 & -0.39 \\
\hline
\end{tabular}

The skewness determined in the study (Skewness $=-1.01$ ) provides an opportunity to conclude that the obtained data on the monitoring of learning are highly skewed, which in turn indicates that some students had experienced problems in monitoring the learning process. The primary school students have to learn to choose appropriate strategies that can facilitate the monitoring of their learning. Fluminhan and her colleague have also found that even students in 6th grade did not skilfully use learning strategies (Fluminhan \& Murgo, 2019). 
There are no significant differences between the teacher's assessment of students' SRL skill and the students' self-assessment. The study determined that there is a relationship between the skills to monitor learning and outcomes assessment $(r=0.738, p<0.01$ ), but if the students can set the learning outcomes in the lesson, he will understand what should be done differently next time $(r=0.822, p<0.01)$.

\section{Conclusion}

The results obtained in the study show that the teacher's assessment and students' self-assessment are similar. From the teacher's point of view, the primary school students' skill to monitor their learning and assess the outcomes are at a medium level, but the skill to set learning outcomes at a low level. The students also acknowledged that defining learning outcomes is at a low level. To prevent that, the teachers should not mention the learning outcomes at the beginning of the music lesson but should encourage and engage students to formulate the achievement by themselves. Although, both the teacher and students have found that monitoring and assessing of learning outcomes at a low level, this study shows that without teacher involvement, the students cannot reach a high level of SRL skills by themselves. That is why primary school teachers should pay particular attention to the selection and learning of the appropriate assessment and problem-solving strategies. Only strong motivation to establish cooperation can promote the development of primary school students' SRL skills during the process of making music. In a further study, it would be useful in music lessons to provide students with techniques for setting learning outcomes and various strategies of monitoring and assessing learning outcomes and then repeating the diagnosis to make general conclusions.

\section{References}

Adeyemi, B. A. \& Oderinde, D. B. (2019). Concept and Relevant Theories of Self-Directed Learning in the Teaching and Learning Process. SSRG International Journal of Humanities and Social Science, 6(3), 46-55.

Benders, D. (2013). Approach to Effective Practice Strategies in Music David Benders. Sport and Art, 1(2), 46-48.

Boekaerts, M. \& Corno, L. (2005). Self-Regulation in the Classroom: A Perspective on Assessment and Intervention. Applied Psychology: An International Review, 54(2), 199-231.

Boyer, S. L., Edmondson, D., R. Artis, A. B. \& Fleming, D. (2013). Self-Directed Learning: A Tool for Lifelong Learning, Journal of Marketing Education, 36(1), 20-32.

Callan, G. L. \& Shim, S. S. (2019). How Teachers Define and Identify Self-Regulated Learning. The Teacher Educator, 54(3), 295-312. 
Cleary, T. J. (2018). The Self-Regulated Learning Guide Teaching Students to Think in the Language of Strategies. New York, London: Routledge.

Council of European Union (2018). Council recommendation of 22 May 2018 on key competences for lifelong learning. Official Journal of the European Union, C189, 2.

De Smul, M., Heirweg, S., Devos, G. \& Van Keer, H. (2018). School and teacher determinants underlying teachers' implementation of self-regulated learning in primary education. Research Papers in Education, 34(6), 701-724.

Dignath, C., Buettner, G. \& Langfeldt, H. P. (2008). How can primary school students learn self-regulated learning strategies most effectively? A meta-analysis on selfregulation training programmes. Educational Research Review, 3(2), 101-129.

Du Toit-Brits, C. (2019). A Focus on Self-directed Learning: The Role that Educators Expectation Play in the Enhancement of Students' Self-directedness. South African Journal of Education, 39(2), 1-11.

Fluminhan, C. S. \& Murgo, C. S. (2019). Academic self-regulation and learning strategies assessed in elementary school students. Psicologia Escolar e Educacional, 23(5), 1-8.

Harding, S., Nibali, N., English, N., Griffin, P., Graham, L. \& Alom, B. M. et al. (2018). Self-regulated learning in the classroom: Realising the potential for Australia's high capacity students. Melbourne: Assessment Research Centre, Melbourne Graduate School of Education. Retrieved from https://education.unimelb.edu.au/_data/assets/ pdf_file/0007/2811706/Self-regulated-learning-in-the-classroom.pdf.

Jaleel, S. \& Anuroofa, O. M. (2017). A Study on the Relationship between Self Directed Learning and Achievement in Information Technology of Students at Secondary Level. Universal Journal of Educational Research, 5(10), 1849-1852.

McPherson, G. E., Miksza, P. \& Evans, P. (2017). Self-Regulated Learning in Music Practice and Performance. In P. A. Alexander, D. H. Schunk \& J. A. Greene (Eds.). Handbook of Self-Regulation of Learning and Performance, $2^{\text {nd }}$ ed. (pp. 181-193). New York, London: Routledge.

Oates, S. (2019). The Importance of Autonomous, Self-Regulated Learning in Primary Initial Teacher Training. Frontiers in Education, 4, Article 102, 1-8.

Peeters, J., Backer, F. D., Reina, V. R., Kindekens, A., Buffel, T. \& Lombaerts, K. (2014). The role of teachers' self-regulatory capacities in the implementation of self-regulated learning practices. Procedia - Social and Behavioral Sciences, 116, 1963-1970.

Penetration skills (Caurviju prasmes). (2020). Skola 2030. Retrieved from https://www. skola2030.lv/lv/macibu-saturs/merki-skolenam/caurviju-prasmes (in Latvian).

Regulations of the National Standard in Primary Education and the Primary Education Subjects Standards and Program Samples (Noteikumi par valsts pamatizglitiibas standartu, pamatizglìtības mācību priekšmetu standartiem un pamatizglìtības programmu paraugiem). (2018). MK noteikumi Nr. 747 no 27.11.2018. Rīga: LR MK. [online] [06.06.2020]. Retrieved from https://likumi.lv/ta/id/303768-noteikumi-parvalsts-pamatizglitibas-standartu-un-pamatizglitibas-programmu-paraugiem (in Latvian).

Thornton, K. (2010). Supporting Self-Directed Learning: A Framework for Teachers. Language Education in Asia, 1(1), 158-170.

Vandeveldea, S., Vandenbussche, L. \& Van Keer, H. (2012). Stimulating self-regulated learning in primary education: Encouraging versus hampering factors for teachers. Procedia - Social and Behavioral Sciences, 69, 1562-1571.

Walsh, K. (2017). Self-directed learning at the point of care, 10(3), InnovAiT, 178-182. 
Zimmerman, B. J. (2002). Becoming a Self-Regulated Learner: An Overview. Theory into Practice, 41(2), 64-70.

Zimmerman, B. J. (2011). Motivational Sources and Outcomes of Self-Regulated Learning and Performance. In B. J. Zimmerman \& D. H. Schunk (Eds.). Handbook of SelfRegulated Learning and Performance (pp. 49-64). New York, London: Routledge. 